\title{
PENGARUH CORPORATE HEDGING TERHADAP COST OF DEBT
}

\author{
Vicki Lineous Suryagari \\ Fitri Ismiyanti \\ Departemen Manajemen Fakultas Ekonomi dan Bisnis \\ Universitas Airlangga
}

E-mail: fitri.ismiyanti@feb.unair.ac.id

\begin{abstract}
ABSTRAK
Berlangsungnya era globalisasi yang ditandai dengan adanya perdagangan bebas, akan membawa dampak ketidakpastian bagi perekonomian Indonesia. Ketidakpastian tersebut meliputi fluktuasi nilai tukar, suku bunga, dan harga komoditas. Hal tersebut tentu akan menimbulkan risiko, termasuk risiko finansial yang dapat meningkatkan cost of debt perusahaan sebagai premi risiko untuk investor. Penelitian ini bertujuan untuk mengetahui pengaruh hedging yang dihitung menggunakan variabel dummy terhadap cost of debt yang diproksikan dengan yield spread. Selain itu bond age, credit rating, leverage, dan profitability digunakan sebagai variabel kontrol dalam penelitian ini. Sampel yang digunakan adalah perusahaan manufaktur yang menerbitkan obligasi dan terdaftar di Bursa Efek Indonesia (BEI) periode tahun 2009-2015. Hasil regresi linier berganda menunjukkan bahwa hedging berpengaruh negatif signifikan terhadap cost of debt. Bond age dan credit rating berpengaruh negatif signifikan terhadap cost of debt. Leverage berpengaruh positif tidak signifikan terhadap cost of debt. Profitability berpengaruh negatif tidak signifikan terhadap cost of debt. Hedging menurunkan cost of debt melalui penurunan biaya kebangkrutan, biaya agensi, dan asimetri informasi. Sehingga perusahaan yang menggunakan hedging akan memiliki cost of debt yang lebih rendah dibandingkan bukan pengguna.
\end{abstract}

Kata kunci: hedging, cost of debt, financial risk

\begin{abstract}
The ongoing globalization era is marked by free trade, will bring uncertainty to the Indonesian economy. These uncertainties include fluctuations of exchange rate, interest rates, and commodity prices. This will certainly pose risks, including financial risks that can increase the firm's cost of debt as a risk premium for investors. This study aims to determine the effect of hedging calculated using dummy variable to cost of debt proxies with yield spread. In addition, the bond age, credit rating, leverage, and profitability are used as control variables. The sample which used is manufacturing firm that issues bonds and is listed on the Indonesia Stock Exchange (IDX) for the period 2009-2015. The result of multiple linear regression shows that hedging has a significant negative effect on the cost of debt. Bond age and credit rating have a significant negative effect on cost of debt. Leverage has no significant positive effect on cost of debt. Profitability has no significant negative effect on cost of debt. Hedging lowers cost of debt through decreased bankruptcy costs, agency costs, and information asymmetry. So firms that use hedging will have a lower cost of debt than non-users.
\end{abstract}

Keywords: hedging, cost of debt, financial risk 


\section{Vicki Lineous Suryagari \\ Fitri Ismiyanti}

\section{Pendahuluan}

Berlangsungnya era globalisasi ditandai dengan semakin maraknya perdagangan bebas. Perdagangan bebas di masa mendatang akan diwarnai dengan persaingan yang semakin tinggi, serta harga pasar yang semakin berfluktuasi yang mengakibatkan ketidakpastian usaha semakin sulit untuk dikendalikan. Perdagangan yang melibatkan dua negara atau lebih akan menimbulkan adanya transaksi dengan mata vang yang berbeda. Perubahan kurs mata uang dapat menimbulkan risiko keuangan bagi perusahaan. Selain itu pihak lain yang akan ikut terdampak adalah pemerintah. Jika kurs rupiah semakin melemah tentu pemerintah harus mengeluarkan rupiah dalam jumlah yang lebih banyak untuk melunasi utangnya. Dengan kata lain jumlah utang yang ditanggung semakin tinggi, tetapi tidak diperoleh tambahan manfaatnya.

Lebih jauh lagi terlepas sebagai eksportir ataupun importir, sebagaimana yang dihadapi oleh pemerintah, perusahaan juga akan merasakan dilema ketika membahas kebijakan struktur modalnya. Struktur modal berkaitan dengan pembelanjaan jangka panjang suatu perusahaan yang diukur dengan perbandingan utang jangka panjang dengan modal sendiri (Sudana, 2011: 143). Penyusunan struktur modal menjadi sangat penting karena dalam pengembangan aktiva perusahaan akan melibatkan investasi jangka panjang dalam jumlah yang tidak kecil.

Utang dapat ditempuh melalui beberapa cara, termasuk obligasi. Obligasi merupakan pernyataan utang yang dikeluarkan oleh pihak penerbit kepada pihak pemegang obligasi. Pemegang obligasi hanya bertindak sebagai kreditur yang tidak ikut campur tangan dalam pengambilan keputusan perusahaan. Pihak manajemen juga tidak bertanggungjawab melaporkan kondisi perusahaan kepada pemegang obligasi.

Langkah yang dapat dilakukan untuk menghadapi risiko ketidakpastian nilai tukar seperti yang telah dijelaskan sebelumnya adalah hedging. Peraturan Menteri Keuangan Republik Indonesia Nomor 12/PMK.08/2013 tentang transaksi lindung nilai dalam pengelolaan utang pemerintah, lindung nilai adalah kegiatan yang dilakukan untuk memitigasi risiko atau melindungi posisi nilai suatu aset atau kewajiban yang mendasarinya terhadap risiko fluktuasi tingkat bunga dan nilai mata vang di masa yang akan datang.

Chen dan King (2014) melakukan penelitian yang bertujuan untuk mengetahui dampak penggunaan hedging terhadap cost of debt, biaya utang yang timbul karena adanya penerbitan obligasi. Dengan menggunakan sampel perusahaan di Amerika Serikat tahun 1994-2004, ditemukan bahwa hedging dapat menurunkan cost of debt melalui menurunkan bankruptcy cost dan agency cost, serta pengurangan information asymmetry. 


\section{Jurnal Manajemen Teori dan Terapan \\ Tahun 10. No. 2, Agustus 2017}

Penelitian semacam ini penting untuk dilakukan. Karena sebagian besar perusahaan memilih alternatif pembiayaan utang sebagai sumber modal utama untuk menjalankan operasi perusahaan. Jika dibandingkan dengan penelitian sebelumnya yang dilakukan di Amerika, mungkin beberapa faktor akan berbeda adanya di Indonesia, misalnya kebijakan pemerintah. Dan keadaan ekonomi global seperti sekarang ini menuntut para pelaku ekonomi seperti perusahaan, untuk lebih tanggap terhadap risiko. Selain itu, di Indonesia instrumen derivatif juga belum terlalu banyak diperdagangkan, meskipun di luar negeri (khususnya di negara maju), pertumbuhan instrumen tersebut berkembang cukup pesat. Dengan demikian, sangat bermanfaat jika dilakukan penelitian serupa di Indonesia.

\section{Landasan Teori}

\section{Cost of Debt}

Cost of debt merupakan return yang disyaratkan oleh kreditur atas dana yang dipinjamkan kepada perusahaan. Secara sederhana cost of debt adalah tingkat suku bunga yang harus dibayar atas suatu pinjaman, dan suku bunga tersebut bisa diobservasi di pasar keuangan. Sebagai contoh, jika suatu perusahaan memiliki obligasi yang beredar, kemudian yield to maturity obligasi tersebut sama dengan suku bunga yang disyaratkan pasar atas utang perusahaan (Ross dkk., 2008: 485).

Dalam penelitian ini cost of debt diidentikkan dengan biaya yang timbul dari penggunaan obligasi sebagai sumber dana yang digunakan oleh perusahaan. Hal ini mengacu pada penelitian sebelumnya yang dilakukan oleh Colla et al. (2013) dan Rauh dan Sufi (2011), yang menyoroti peran dominan obligasi sebagai komponen modal perusahaan.

Perhitungan cost of debt dapat dilakukan dengan menggunakan yield spread, seperti penelitian sebelumnya yang dilakukan oleh Klock et al. (2005). Yield spread dapat didefinisikan sebagai selisih antara yield obligasi yang diterbitkan oleh perusahaan dan pemerintah, yang periodenya disesuaikan dengan periode penelitian. Apabila dirumuskan menjadi:

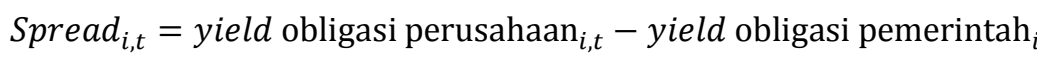

\section{Hedging}

Johansyah $(2013,43: 2)$ menyebutkan hedging sebenarnya mirip dengan praktik manajemen risiko lain seperti asuransi yang lebih dikenal dan digunakan oleh masyarakat. Hedging erat kaitannya dengan instrumen derivatif yang digunakan untuk melindung-nilaikan suatu aset yang dimiliki perusahaan. Menurut McDonald (2009: 2) derivatif adalah sebuah instrumen kevangan (atau lebih sederhananya, sebuah persetujuan antara dua pihak) yang memiliki 


\section{Vicki Lineous Suryagari \\ Fitri Ismiyanti}

nilai yang diukur dengan harga sesuatu yang lain. Utomo (2000) menyebutkan bahwa instrumen derivatif bukan sebuah klaim atas arus pendapatan seperti layaknya saham dan obligasi. Sebaliknya, instrumen derivatif merupakan kontrak perjanjian antara dua pihak untuk menjual atau membeli sejumlah barang, (baik itu aktiva finansial maupun komoditas) pada tanggal tertentu di masa datang dengan harga yang telah disepakati saat ini. Penggunaan hedging di Indonesia dapat dikatakan belum terlalu banyak. Oleh karena itu instrumen derivatif juga belum terlalu banyak diperdagangkan di Indonesia. Beberapa instrumen derivatif yang digunakan oleh perusahaan untuk melakukan hedging adalah kontrak forward, kontrak future, opsi, dan swaps.

Hedging dalam penelitian ini dapat diukur dengan menggunakan dummy. Dengan mengidentifikasi laporan keuangan perusahaan yang telah dipublikasikan, apabila tertera informasi sekurang-kurangnya suatu perusahaan menggunakan salah satu jenis instrumen derivatif maka perusahaan tersebut diberi nilai 1. Sedangkan bagi perusahaan yang tidak melakukan hedging diberi nilai 0 .

\section{Hedging Mengurangi Bankruptcy Cost}

Probabilitas terjadinya kebangkrutan (bankruptcy) akan semakin tinggi ketika arus kas semakin tidak stabil. Arus kas yang tidak stabil akan mempengaruhi kemampuan perusahaan untuk memenuhi kewajibannya. Perusahaan yang menggunakan leverage sebagai sumber permodalannya menjadi lebih rentan dengan risiko kebangkrutan karena penggunaan utang tersebut menimbulkan biaya bunga yang dianggap sebagai biaya tetap finansial. Akibatnya perusahaan akan menghadapi risiko finansial. Risiko finansial sebagai tambahan risiko dari penggunaan utang, dapat menimbulkan adanya kemungkinan perusahaan tidak bisa membayar biaya bunga atas utang tersebut yang disebut risiko gagal bayar (default risk). Default risk yang tinggi akan meningkatkan risiko kebangkrutan.

Penelitian Smith dan Stulz (1985) menyebutkan bahwa penggunaan hedging dapat mengurangi ketidakstabilan cash flow. Dengan demikian kemampuan perusahaan untuk memenuhi kewajibannya akan membaik dan risiko kebangkrutan akan turun. Jika risiko kebangkrutan semakin turun, maka biaya kebangkrutan yang harus ditanggung akan semakin kecil.

\section{Hedging Menurunkan Agency Cost of Debt}

Masalah underinvestment adalah masalah keagenan (agency problem) dimana perusahaan menolak berinvestasi pada aset berisiko rendah, untuk memaksimalkan kekayaan mereka atas biaya pemegang utang (cost of the debt holders). Proyek berisiko 


\section{Jurnal Manajemen Teori dan Terapan \\ Tahun 10. No. 2, Agustus 2017}

rendah memberikan lebih banyak keamanan bagi pemegang utang, karena menghasilkan arus kas perusahaan lebih stabil untuk melunasi kreditur. Sebaliknya, arus kas yang terlalu stabil tidak menghasilkan profit berlebih bagi para pemegang saham. Akhirnya proyek tersebut akan ditolak, meskipun meningkatkan nilai perusahaan. Froot et al. (1993) berpendapat bahwa hedging mengurangi masalah underinvestment ketika perusahaan menghadapi peluang untuk tumbuh dan biaya pendanaan eksternal yang tinggi. Dalam hal ini hedging mengarah pada manajer yang mengikuti kebijakan investasi optimal dengan menghasilkan dana internal yang cukup dan memiliki biaya modal yang rendah.

Pemegang saham (shareholders) menolak berpartisipasi dalam proyek berisiko rendah serupa dengan masalah pengalihan risiko (atau substitusi aset), dimana pemegang saham dapat menukarkan aset berisiko rendah dengan berisiko tinggi. Kedua hal tersebut akan meningkatkan nilai pemegang saham dengan mengorbankan pemegang utang. Proyek berisiko tinggi memberikan keuntungan yang lebih besar bagi pemegang saham melalui peningkatan pendapatan, sedangkan pemegang utang hanya membutuhkan bagian arus kas yang stabil. Masalahnya adalah pemegang utang tidak memperoleh kompensasi atas tambahan risiko tersebut dan memproyeksikan bila ada kemungkinan default yang signifikan. Penelitian Campbell dan Kracaw (1990) mendukung bahwa hedging dapat mengurangi masalah pengalihan risiko melalui pengurangan risiko finansial dan volatilitas pengembalian aset. Sehingga hedging dapat menurunkan cost of debt, terutama pada perusahaan yang menghadapi agency problem lebih tinggi.

\section{Hedging Menurunkan Tingkat Information Asymmetry}

Penyebab terjadinya agency problem adalah adanya asimetri informasi (information asymmetry). Dalam pembahasan ini, diasumsikan bahwa manajer memiliki informasi yang lebih banyak tentang kinerja perusahaan, daripada stakeholders yang berada di luar perusahaan. Dalam keadaan seperti ini, manajer memiliki kewenangan apakah ia akan mengeluarkan atau tidak sebagian atau keseluruhan informasi perusahaan kepada stakeholders. Ketika manajer memilih untuk tidak mengumumkan informasi perusahaan secara keseluruhan, maka investor tidak memiliki informasi keseluruhan perusahaan. Akibatnya, informasi asimetri mempengaruhi harga aset ekuilibrium dan tingkat pengembalian yang diharapkan melalui penilaian investor mengenai distribusi arus kas masa depan.

DaDalt et al. (2002) menemukan bahwa penggunaan instrumen derivatif (hedging) dapat menurunkan tingkat asimetri informasi, karena bisa mengurangi volatilitas arus kas, dan arus kas dapat diprediksi. Hal ini dapat memperbaiki penilaian investor terhadap kinerja perusahaan, dengan kata lain information asymmetry dapat diperbaiki melalui hedging. 


\section{Vicki Lineous Suryagari \\ Fitri Ismiyanti}

$\mathrm{H1}$ : Hedging berpengaruh negatif terhadap cost of debt.

\section{Obligasi}

Bursa Efek Indonesia (BEI) mendefinisikan obligasi sebagai surat utang jangka menengahpanjang yang dapat dipindahtangankan yang berisi perjanjian antara pihak penerbit untuk membayar imbalan berupa bunga pada periode tertentu dan melunasi pokok utang pada waktu yang telah ditentukan kepada pihak pembeli obligasi tersebut. Obligasi merepresentasikan sekuritas utang jangka panjang yang diterbitkan oleh agensi pemerintah atau korporasi (Madura, 2003:158).

Beberapa faktor yang mempengaruhi nilai obligasi antara lain sebagai berikut:

\section{Bond Age}

Bond age merupakan selisih antara periode penerbitan obligasi dengan periode penelitian ini yang dinyatakan dalam tahun. Chen dan King (2014) menyebutkan bond age merupakan jumlah periode (tahun) obligasi sejak diterbitkannya obligasi tersebut. Sehingga dapat dirumuskan sebagai berikut:

Bond age $=$ Year of bond issue - Year of observation

Bond age digunakan sebagai proksi likuiditas obligasi. Semakin baru waktu penerbitan obligasi, maka semakin baik likuiditas dari obligasi tersebut. Penelitian Chen dan King (2014) membuktikan hubungan positif antara bond age dan cost of debt, karena obligasi yang lebih tua biasanya membawa risiko likuiditas yang lebih tinggi. Sehingga semakin lama umur suatu obligasi akan menimbulkan biaya yang lebih tinggi. Dengan demikian bond age berpengaruh positif terhadap yield spread.

$\mathrm{H} 2$ : Bond age berpengaruh positif terhadap cost of debt.

\section{Credit Rating}

Rating obligasi (bond rating) adalah simbol-simbol karakter yang diberikan oleh agen pemeringkat untuk menunjukkan risiko obligasi (Hartono, 2014: 230). Oleh karena itu, pada umumnya rating obligasi digunakan sebagai proksi dari risiko obligasi. Di Indonesia obligasi diperingkat oleh PT PEFINDO dan PT KASNIC. Namun yang lebih sering digunakan adalah rating obligasi dari PT PEFINDO.

Menurut Hartono (2014) risiko dari obligasi adalah kemungkinan obligasi tidak terbayar (default). Semakin tinggi rating menunjukkan bahwa penerbit obligasi mempunyai kemampuan yang sangat kuat untuk membayar kembali obligasi tersebut beserta bunganya, dan berlaku sebaliknya. Dengan demikian credit rating akan berpengaruh negatif, karena semakin rendah credit rating dan semakin tinggi default risk-nya maka semakin tinggi biaya utang. 
H3: Credit rating berpengaruh negatif terhadap cost of debt.

\section{Karakteristik Perusahaan}

Karakteristik perusahaan digunakan sebagai determinan variabel dependen, karena perusahaan merupakan objek utama dalam penelitian. Beberapa karakteristik tersebut antara lain:

\section{Leverage}

Leverage mengukur berapa besar penggunaan utang dalam pembelanjaan perusahaan (Sudana, 2011: 20). Dengan kata lain leverage menunjukkan tingkat utang yang dimiliki oleh perusahaan. Penggunaan utang termasuk obligasi yang diterbitkan oleh perusahaan akan menimbulkan biaya bunga. Dengan demikian semakin tinggi utang yang dimiliki perusahaan, maka semakin tinggi biaya bunga yang harus dibayar. Biaya bunga yang tinggi akan meningkatkan risiko finansial sampai pada default risk. Default risk yang tinggi akan menimbulkan risiko kebangkrutan yang berimbas pada biaya kebangkrutan. Dengan demikian leverage berpengaruh positif terhadap cost of debt.

Berdasarkan penelitian Chen dan King (2014), leverage dapat dirumuskan sebagai berikut:

Leverage $=\frac{\text { Total debt }}{\text { Total market value of assets }}$

Dimana,

Market value of assets $=$ total debt + market value of equity

H4: Leverage berpengaruh positif terhadap cost of debt.

\section{Profitability}

Profitability menunjukkan kombinasi dampak dari likuiditas, manajemen aset, dan manajemen utang terhadap keseluruhan hasil operasional perusahaan (Cornett et al., 2012: 82-83). Profitability mencerminkan keuntungan yang diperoleh perusahaan. Tingkat keuntungan tersebut biasanya dilihat dari perolehan laba perusahaan pada laporan laba/rugi. Semakin tinggi laba yang diperoleh, maka akan memungkinkan perusahaan akan memilih menggunakan laba ditahannya sebagai sumber modal. Dengan demikian penggunaan utang perusahaan akan menurun, dan akan mengurangi cost of debt. Sehingga profitability akan berpengaruh negatif terhadap cost of debt.

Dalam penelitian ini, profitability dapat dirumuskan sebagai berikut:

Profitability $=\frac{\text { Earnings Before Interest \& Tax }}{\text { Total Assets }}$ 
Vicki Lineous Suryagari

Fitri Ismiyanti

H5: Profitability berpengaruh negatif terhadap cost of debt.

\section{Model Analisis}

Model analisis yang digunakan untuk mengetahui pengaruh penggunaan hedging, bond age, credit rating, leverage, dan profitability terhadap cost of debt adalah persamaan regresi linear berganda yang dirumuskan sebagai berikut:

Yield spread $_{i, t}=$

$$
\begin{aligned}
& \alpha+\beta_{1} \text { Hedging }_{i, t}+\beta_{2} \text { Bond age }_{i, t}+\beta_{3} \text { Credit rating }_{i, t}+\beta_{4} \text { Leverage }_{i, t}+ \\
& \beta_{5} \text { Profitability }_{i, t}+\varepsilon
\end{aligned}
$$

\begin{tabular}{|c|c|}
\hline a & $=\mathrm{kon}$ \\
\hline$\beta_{1}, \beta_{2}, \ldots, \beta_{7}$ & = koefisien regresi \\
\hline eld spread $_{i, t}$ & $\begin{aligned}= & \text { selisih antara yield obligasi perusahaan i dengan yield obligasi yang } \\
& \text { diterbitkan pemerintah pada periode t. } \\
& \text { Digunakan sebagai proksi dari cost of debt perusahaan. }\end{aligned}$ \\
\hline Hedging $_{i, t}$ & $\begin{array}{l}=\text { variabel dummy yang akan bernilai } 1 \text { jika perusahaan i menerapkan } \\
\text { sekurang-kurangnya satu jenis hedging dan } 0 \text { untuk perusahaan i } \\
\text { yang tidak menerapkan hedging pada periode t. }\end{array}$ \\
\hline Bond $_{\text {age }} e_{i, t}$ & = umur obligasi perusahaan i yang pada periode t. \\
\hline Credit rating ${ }_{i, t}$ & $\begin{aligned}= & \text { rating credit obligasi perusahaan i yang diberikan oleh PEFINDO } \\
& \text { pada periode } t .\end{aligned}$ \\
\hline Leverage $_{i, t}$ & $\begin{aligned}= & \text { perbandingan total debt dengan total market value of assets } \\
& \text { perusahaan i pada periode } t .\end{aligned}$ \\
\hline Profitability $_{i, t}$ & $\begin{aligned}= & \text { rasio EBIT (earning before interes and tax) terhadap total assets } \\
& \text { perusahaan i pada periode } t .\end{aligned}$ \\
\hline & $=\operatorname{ting}$ \\
\hline
\end{tabular}

Keterangan:

\section{Metode Penelitian}

Penelitian ini menggunakan pendekatan kuantitatif untuk menjawab rumusan masalah yang ada. Pendekatan ini dilakukan melalui pengujian hipotesis dengan mempertimbangkan variabel-variabel yang digunakan, hubungan antar variabel-variabel tersebut, dan kesesuaian dengan rumusan masalah yang diajukan. Selanjutnya dilakukan pengukuran data, dan penarikan kesimpulan.

\section{Jenis dan Sumber Data}

Data yang digunakan dalam penelitian ini adalah data sekunder yang diperoleh dari laporan tahunan perusahaan manufaktur yang terdaftar di Bursa Efek Indonesia selama 
periode 2009-2015. Selain itu, data juga didapatkan dari website Bursa Efek Indonesia (www.idx.co.id) dan PEFINDO.

\section{Prosedur Pengumpulan Data}

Tahap-tahap pengumpulan data dari penelitian ini, antara lain:

1. Studi kepustakaan dilakukan dengan cara mencari, mengumpulkan, dan mempelajari jurnal, paper, buku, atau sumber lain dari media cetak ekonomi yang berhubungan dengan topik dan permasalahan yang dibahas dalam penelitian.

2. Data melalui media internet, diperoleh dengan mengunjungi alamat website instansiinstansi terkait seperti IDX dan PEFINDO untuk memenuhi data-data yang dibutuhkan dalam penelitian.

\section{Populasi dan Sampel Penelitian}

Populasi dalam penelitian ini adalah perusahaan yang terdaftar di Bursa Efek Indonesia (BEI) tahun 2009-2015. Sampel ditentukan dengan metode purposive sampling, harus memenuhi kriteria berikut:

1. Perusahaan manufaktur terdaftar di Bursa Efek Indonesia (BEI) tahun 2009-2015.

2. Perusahaan menerbitkan obligasi selama periode penelitian, yaitu tahun 2009-2015.

3. Perusahaan mempublikasikan laporan keuangan dan tahunan untuk tahun fiskal 2009-2015 dengan ketersediaan data yang dibutuhkan untuk penelitian.

4. Menghadapi sekurang-kurangnya salah satu diantara risiko nilai tukar, risiko tingkat suku bunga, dan risiko harga komoditas.

\section{Definisi Operasional}

Berikut adalah definisi operasional dan rumus perhitungan dari variabel-variabel yang akan digunakan dalam penelitian ini:

1. Cost of debt dalam penelitian ini bukan merupakan biaya utang yang sesungguhnya, tetapi merepresentasikan premi risiko. Dimana cost of debt dihitung menggunakan yield spread sesuai dengan persamaan (2.1).

2. Hedging merupakan variabel dummy yang menandakan suatu perusahaan melakukan hedging. Perusahaan yang sekurang-kurangnya menggunakan satu jenis instrumen derivatif diberi nilai 1 (satu), dan 0 (nol) bagi non-pengguna.

3. Bond age merupakan selisih antara periode penerbitan obligasi dengan periode penelitian ini yang dinyatakan dalam tahun, yang dihitung menggunakan persamaan (2.2).

4. Credit rating diukur dengan melihat rating yang diberikan oleh badan pemberi rating obligasi yaitu PEFINDO. Kemudian rating tersebut akan diberi score yang baru, sehingga nilai akan berada pada kisaran 1/19 hingga 19/19. 
Vicki Lineous Suryagari

Fitri Ismiyanti

5. Leverage merupakan tingkat utang yang dimiliki oleh perusahaan selama periode penelitian, yang dihitung menggunakan persamaan (2.3).

6. Profitability menunjukkan kemampuan perusahaan untuk memperoleh laba, dihitung menggunakan persamaan (2.5).

\section{Teknik Analisis}

Penelitian ini merupakan penelitian yang bertujuan untuk mengetahui adanya pengaruh variabel independen dan variabel kontrol terhadap variabel dependen yang ada dalam penelitian. Untuk menganalisis data-data yang ada akan digunakan teknik analisis regresi linear berganda. Langkah-langkah yang dilakukan dalam menyusun analisis dalam penelitian ini, antara lain:

1. Menghitung variabel-variabel yang diperlukan dalam penelitian ini.

2. Melakukan Uji Asumsi Klasik
a. Uji Normalitas
b. Uji Multikolinearitas
c. Uji Autokorelasi
d. Uji Heteroskedastisitas

3. Melakukan analisis regresi linear berganda dari hasil perhitungan variabel-variabel tersebut untuk membuktikan hipotesis, dengan bantuan SPSS (Statistical Package for Social Science) 20.

4. Melakukan uji hipotesis secara parsial (uji †) dan simultan (uji F)

5. Melakukan Penilaian Koefisien Determinasi $\left(R^{2}\right)$

\section{Hasil dan Pembahasan}

\section{Deskripsi Hasil Penelitian}

Terdapat tiga jenis variabel yang digunakan dalam penelitian ini. Variabel independen dalam penelitian ini adalah hedging, yang diujikan memberi pengaruh terhadap cost of debt sebagai variabel dependen dengan menggunakan bond age, credit rating, leverage, dan profitability sebagai variabel kontrol. Hasil deskripsi statistik untuk masing-masing variabel tersebut dapat dilihat pada Tabel 1 berikut. 
Tabel 1

Statistik Deskriptif Variabel Penelitian

\begin{tabular}{|c|c|c|c|c|c|}
\hline Variabel & $\mathbf{N}$ & Minimum & Maximum & Mean & Standar Deviasi \\
\hline Yield Spread & 54 & -0.35 & 6.41 & 1.751852 & 1.277511 \\
\hline Hedging & 54 & 0 & 1 & 0.48 & 0.504 \\
\hline Bond Age & 54 & 0 & 8 & 2.26 & 2.121 \\
\hline Credit rating & 54 & 1 & 19 & 14.63 & 4.319 \\
\hline Leverage & 54 & 0.081 & 0.922 & 0.392222 & 0.211799 \\
\hline Profitability & 54 & -0.033 & 0.988 & 0.15413 & 0.1793381 \\
\hline Valid N (listwise) & 54 & & & & \\
\hline
\end{tabular}

Sumber: data merupakan output SPSS 20 yang sudah diolah

Berdasarkan Tabel 1 variabel cost of debt (yield spread) memiliki nilai terendah -0,35 dan nilai tertinggi 6,41 dengan nilai rata-rata sebesar 1,751852 yang menunjukkan bahwa nilai ratarata cost of debt perusahaan manufaktur tahun 2009-2015 adalah sebesar 1,751852. Standar deviasi untuk variabel cost of debt adalah sebesar 1,277511, nilai tersebut lebih kecil dari pada nilai rata-rata. Hal ini menunjukkan penyimpangan sebaran data yang kecil. Berdasarkan Tabel 1 variabel hedging memiliki nilai rata-rata sebesar 0,48 dengan standar deviasi sebesar 0,504. Standar deviasi yang lebih besar dari pada nilai rata-rata menunjukkan adanya penyimpangan sebaran data yang lebih besar.

Berdasarkan tabel 1 variabel bond age memiliki nilai terendah 0 dan nilai tertinggi 8 . Nilai rata-rata bond age adalah sebesar 2,26, dimana angka tersebut menunjukkan rata-rata umur obligasi yang diterbitkan perusahaan manufaktur tahun 2009-2015 adalah 2,26. Variabel bond age memiliki standar deviasi yang lebih kecil dari nilai rata-ratanya yakni sebesar 2,121, dimana angka tersebut menunjukkan penyimpangan sebaran data yang lebih kecil.

Berdasarkan Tabel 1 nilai terendah variabel credit rating pada penelitian ini adalah 1 , sedangkan nilai tertingginyaya adalah 19. Variabel credit rating memiliki nilai rata-rata sebesar 14,63 dengan standar deviasi sebesar 4,319. Nilai standar deviasi yang lebih kecil dari nilai rata-rata tersebut menunjukkan penyimpangan sebaran data yang kecil.

Berdasarkan Tabel 1 variabel leverage memiliki nilai terendah 0,081 dan nilai tertinggi 0,922 dengan nilai rata-rata 0,392222 yang menunjukkan bahwa rata-rata leverage perusahaan manufaktur tahun 2009-2015 adalah sebesar 0,392222. Variabel leverage memiliki standar deviasi yang lebih kecil dari nilai rata-ratanya yakni sebesar 0,21 1799, dimana angka tersebut menunjukkan penyimpangan sebaran data yang lebih kecil. 
Vicki Lineous Suryagari

Fitri Ismiyanti

Berdasarkan Tabel 1 variabel profitability memiliki nilai terendah $-0,033$ dan nilai tertinggi 0,988 dengan nilai rata-rata 0,15413 yang menunjukkan bahwa rata-rata profitability perusahaan manufaktur tahun 2009-2015 adalah sebesar 0,15413. Variabel profitability memiliki standar deviasi yang lebih besar dari nilai rata-ratanya yakni sebesar 0,1793381, dimana angka tersebut menunjukkan penyimpangan sebaran data yang besar.

\section{Analisis Model dan Pengujian Hipotesis}

Penelitian ini menggunakan analisis regresi linear berganda dengan bantuan program SPSS 20.0 (Statistical Program for Social) untuk mengetahui pengaruh hedging sebagai variabel independen dan bond age, credit rating, leverage, dan profitability sebagai variabel kontrol terhadap cost of debt sebagai variabel dependen yang diproksikan menggunakan yield spread. Hasil analisis regresi linear berganda untuk penelitian ini akan ditampilkan pada Tabel 2 berikut.

Tabel 2

Hasil Analisis Regresi Linear Berganda

\begin{tabular}{|l|c|c|c|}
\hline \multicolumn{1}{|c|}{ Variabel } & Koefisien & $\mathbf{t}$ & Sig. $\mathbf{~}$ \\
\hline Hedging & $-0,428$ & $-1,729$ & 0,090 \\
\hline Bond Age & $-0,213$ & $-2,735$ & 0,009 \\
\hline Credit Rating & $-0,244$ & $-6,590$ & 0,000 \\
\hline Leverage & 0,592 & 0,671 & 0,505 \\
\hline Profitability & $-0,605$ & $-0,804$ & 0,425 \\
\hline \multicolumn{3}{|c|}{0,869} \\
\hline Konstanta & 0,618 \\
\hline R. Square & 0,579 \\
\hline Adj. R. Square & \multicolumn{3}{|c|}{15,558} \\
\hline F hitung & 0,000 \\
\hline Sig. &
\end{tabular}

Signifikansi pada $a=10 \%$

Sumber: data merupakan output SPSS 20 yang sudah diolah

Berdasarkan Tabel 2 tersebut, dapat dirumuskan model persamaan regresi sebagai berikut:

Yield spread $=5,869-0,428$ Hedging $-0,213$ Bond age $-0,244$ Credit rating ${ }_{i, t}+0,592$ Leverage

$-0,605$ Profitability $+\varepsilon$

\section{Pembahasan}

1. Hedging

Pada pengujian hipotesis pertama penelitian ini ditemukan bahwa hedging berpengaruh negatif signifikan terhadap cost of debt yang diproksikan sebagai yield spread obligasi. 


\section{Jurnal Manajemen Teori dan Terapan \\ Tahun 10. No. 2, Agustus 2017}

Hal ini menunjukkan bahwa perusahaan yang melakukan hedging akan memiliki cost of debt yang lebih rendah dibandingkan dengan perusahaan yang tidak melakukan hedging. Hedging sebagai salah satu kebijakan yang dapat melindungi arus kas perusahaan dari risiko fluktuasi harga baik berupa suku bunga, nilai tukar, maupun harga komoditas, yang merupakan dampak dari ketidakpastian kondisi ekonomi global. Konsisten dengan penelitian Chen dan King (2014), hedging dapat menurunkan cost of debt melalui penurunan risiko kebangkrutan, biaya agensi, dan pengurangan informasi asimetri.

\section{Bond Age}

Penelitian ini menggunakan bond age sebagai variabel kontrol dengan hasil memiliki pengaruh negatif signifikan terhadap cost of debt. Hasil ini tidak konsisten dengan teori dan hipotesis yang diajukan di awal, yang menyatakan bahwa bond age akan berpengaruh positif terhadap cost of debt. Beberapa penelitian seperti yang dilakukan oleh Anderson (2003) juga berpendapat demikian. la menyatakan bahwa semakin lama umur suatu obligasi, maka obligasi tersebut akan dipandang kurang likuid. Likuiditas yang menurun tersebut akan meningkatkan yield spread. Sehingga perusahaan akan menanggung cost of debt yang tinggi. Namun fakta lain ditemukan dalam penelitian ini. Sebagaimana penelitian yang dilakukan oleh Ziebart dan Reiter (1992) menunjukkan hasil yang berbeda antara umur obligasi terhadap yield obligasi. Umur obligasi justru berpengaruh negatif terhadap terhadap yield spread. Hal ini berarti dengan adanya obligasi yang memiliki umur lebih lama, investor menganggap obligasi tersebut lebih dapat dipercaya dan bagus reputasinya. Sehingga yield yang diharapkan oleh investor akan semakin kecil, dan cost of debt perusahaan akan turun.

3. Credit Rating

Penelitian ini juga menggunakan credit rating sebagai variabel kontrol. Credit rating merupakan peringkat suatu obligasi yang diberikan oleh PEFINDO untuk mencerminkan tingkat risiko obligasi tersebut. Peringkat ini dapat dijadikan sebagai pedoman bagi para investor untuk membeli obligasi. Semakin tinggi credit rating, mencerminkan risiko obligasi yang semakin kecil, berarti semakin tinggi kepercayaan investor terhadap obligasi tersebut. Pada penelitian ini credit rating memiliki pengaruh negatif signifikan terhadap cost of debt. Hal ini dapat diartikan bahwa perusahaan dengan credit rating yang tinggi, dapat menurunkan cost of debt-nya, dibandingkan dengan perusahaan yang memiliki credit rating rendah. Hasil empiris penelitian ini konsisten dengan hasil empiris penelitian Chen dan King (2014), yang menyebutkan bahwa credit rating berpengaruh negatif terhadap cost of debt.

4. Leverage

Leverage yang dijadikan sebagai variabel kontrol dalam penelitian ini terbukti berpengaruh positif tidak signifikan terhadap cost of debt. Hal ini menunjukkan bahwa 
semakin tinggi tingkat leverage perusahaan, maka semakin tinggi pula cost of debt perusahaan. Dari hasil tersebut, mengimplikasikan bahwa dengan tingkat leverage yang tinggi perusahaan harus menanggung biaya bunga yang tinggi dan akan dihadapkan pada risiko gagal bayar (default risk). Dengan kata lain semakin tinggi leverage yang dimiliki perusahaan, maka semakin tinggi risiko finansial perusahaan sehingga akan menimbulkan risiko kebangkrutan (bankruptcy risk). Munculnya risiko kebangkrutan maka akan menimbulkan adanya biaya kebangkrutan (bankruptcy cost). Biaya ini lah yang turut meningkatkan cost of debt yang dalam penelitian ini diproksikan sebagai yield spread. Pada penelitian ini didapatkan hasil yang tidak signifikan atas leverage terhadap yield spread. Hasil tersebut konsisten dengan penelitian yang dilakukan oleh Faizah dkk. (2015). Hal ini mengindikasikan bahwa tinggi atau rendahnya leverage tidak mempengaruhi yield obligasi. Perusahaan dalam menerbitkan obligasi dan memberikan yield tidak ditentukan oleh tingkat leverage yang dimilikinya. Semakin tinggi leverage tidak berpengaruh terhadap besar atau kecilnya yield obligasi. Sehingga leverage perusahaan tidak memiliki pengaruh terhadap yield spread obligasi.

5. Profitability

Berdasarkan hasil penelitian profitability memiliki pengaruh negatif tidak signifikan terhadap cost of debt yang diproksikan sebagai yield spread. Profitability bisa menjadi cerminan kinerja perusahaan dalam memperoleh keuntungan. Tingkat keuntungan tersebut biasanya dilihat dari perolehan laba perusahaan pada laporan laba/rugi. Semakin tinggi laba yang diperoleh, maka akan memungkinkan perusahaan akan memilih menggunakan laba ditahannya sebagai sumber modal. Dengan demikian penggunaan utang perusahaan akan menurun, tak terkecuali perusahaan juga akan mengurangi penerbitan obligasi. Sehingga yield obligasi yang harus dikeluarkan juga akan turun dan akan mengurangi cost of debt. Namun dalam penelitian ini ditemukan hasil yang tidak signifikan. Hasil tersebut konsisten dengan penelitian yang dilakukan oleh Faizah dkk. (2015). Perusahaan dengan profit yang tinggi belum tentu sepenuhnya menggunakan profit tersebut sebagai satu-satunya sumber pendanaan. Besar kecilnya profitability (retained earning) tidak mempengaruhi tingkat utang (termasuk jumlah obligasi yang diterbitkan) maupun yield yang diberikan oleh perusahaan. Sebagaimana dijelaskan pada trade-off theory, perusahaan akan menggunakan utang sampai tingkat tertentu untuk memaksimalkan nilai perusahaan, karena berasumsi bahwa akan memperoleh manfaat pajak akibat penggunaan utang. Dengan demikian sebesar apapun profit, perusahaan akan tetap mempertahankan posisi utangnya (termasuk obligasi yang dimiliki) pada tingkat tertentu. Sehingga profitability tidak akan berpengaruh terhadap yield spread. 


\section{Jurnal Manajemen Teori dan Terapan \\ Tahun 10. No. 2, Agustus 2017}

\section{Simpulan dan Saran}

\section{Simpulan}

Berdasarkan penelitian yang dilakukan pada perusahaan manufaktur yang yang menerbitkan obligasi dan terdftar di Bursa efek Indonesia (BEl) tahun 2009-2015, maka dihasilkan kesimpulan sebagai berikut:

1. Hedging berpengaruh negatif signifikan terhadap cost of debt. Hal ini menunjukkan bahwa perusahaan yang melakukan hedging akan memiliki cost of debt yang lebih rendah dibandingkan dengan perusahaan yang tidak melakukan hedging.

2. Bond age berpengaruh negatif signifikan terhadap cost of debt. Hal ini berarti semakin lama umur suatu obligasi, semakin dipercaya dan bagus reputasi obligasi tersebut.

3. Credit rating berpengaruh negatif signifikan terhadap cost of debt. Hal ini dapat diartikan bahwa perusahaan dengan credit rating yang tinggi, dapat menurunkan cost of debt-nya, dibandingkan dengan perusahaan yang memiliki credit rating rendah.

4. Leverage berpengaruh positif tidak signifikan terhadap cost of debt. Perusahaan dalam menerbitkan obligasi dan memberikan yield tidak ditentukan oleh tingkat leverage yang dimilikinya. Semakin tinggi leverage tidak berpengaruh terhadap besar atau kecilnya yield obligasi.

5. Profitability berpengaruh negatif tidak signifikan terhadap cost of debt. Besar kecilnya profitability (retained earning) tidak mempengaruhi jumlah obligasi yang diterbitkan maupun yield yang diberikan oleh perusahaan.

\section{Saran}

Berdasarkan hasil penelitian dan penarikan kesimpulan, saran yang dapat diajukan oleh peneliti adalah sebagai berikut:

1. Bagi perusahaan, hedging merupakan salah satu kebijakan yang layak untuk dipertimbangkan. Terutama bagi perusahaan yang memiliki usaha dan transaksi yang berkaitan dengan nilai tukar atau suku bunga. Apalagi jika perusahaan memiliki hutang dengan dalam valuta asing dan suku bunga mengambang. Hedging akan sangat dibutuhkan khususnya oleh perusahaan-perusahaan yang sering melakukan ekspor dan impor, untuk menghadapi naiknya suku bunga dan nilai tukar yang fluktuatif. Perusahaan juga harus memperhatikan jangka waktu/umur obligasi yang diterbitkan, menjaga rating perusahaan, serta mengkaji rasio leverage dan profitability sehingga dapat menekan cost of debt.

2. Bagi investor, seharusnya memperhatikan kebijakan hedging, umur obligasi, rating perusahaan, serta rasio leverage dan profitability, sebelum mengambil keputusan 
berinvestasi pada suatu perusahaan. Karena besarnya yield yang akan diperoleh sebanding dengan potensi yang ditanggung.

3. Bagi akademisi dan penelitian selanjutnya, sebaiknya mengaplikasikan penelitian ini pada industri lain diluar manufaktur untuk mengetahui apakah teori hedging berlaku sama pada industri lain tersebut. Selain itu, akan lebih baik jika menambahkan variabel lain seperti umur perusahaan karena berkaitan dengan pengalaman dan perilaku perusahaan dalam menghadapi risiko pada periode-periode sebelumnya. Periode penelitian yang diperpanjang dan jumlah sampel yang diperbanyak, akan memperoleh hasil penelitian yang lebih akurat.

\section{DAFTAR PUSTAKA}

Anderson, Ronald C et al., 2003. Founding Family Ownership and The Agency Cost of Debt. Journal of Financial Economic. 68, 263-285.

Bartram, S.M., Brown, G.W., Conrad, J., 2011. The Effects of Derivatives on Firm Risk and Value. Journal of Finance Quantitative and Analysis. 46, 967-999.

Bodie, Z., Kane, A., Marcus, A. J. 2011 . Investments and Portfolio Management: Global Edition. New York: McGraw Hill.

Bodie, Z., Kane, A., Marcus, A. J., Jain, R. 2014. Investments: Asia Global Edition. New York: McGraw Hill.

Campbell, T. S., Kracaw, W. A., 1990. Corporate Risk Management and Incentive Effects of Debt. Journal of Finance. 45, 1673-1686.

Chen, J., King, Tao-Hsien Dolly, 2014. Corporate Hedging and the Cost of Debt. Journal of Corporate Finance. Vol. 29 (2014), 221-245.

Colla, P., Ippolito, F., Li, K., 2013. Debt Specialization. Journal of Finance. 68, $2117-2141$.

Cornett, M. M., Adair, T. A., Nofsinger, J. 2012. Finance: Applications and Theory. New York: McGraw Hill.

Corrado, C. J., Jordan, B. D. 2002. Fundamentals of Investments: Valuation and Management. New York: McGraw Hill.

Countiho, Joao Ricardo Ribeiro, Hsia Hua Sheng, Mayra Ivanoff Lora. 2012. The Use of Fx Derivatives and Cost of Capital: Evidence of Brazilian Companies. Emerging Markets Review, Vol. 13 (4), 411-423.

DaDalt, P., Gay, G.D., Nam, J., 2002. Asymmetric Information and Corporate Derivatives Use. J. Futur. Mark. 22, 241-267.

Easley, D., O'Hara, M., 2004. Information and the Cost of Capital. Journal of Finance. 59, 15531583. 


\section{Jurnal Manajemen Teori dan Terapan \\ Tahun 10. No. 2, Agustus 2017}

Faizah, YLN., Suyono, E., Ramadhanti W., 2015. Pengaruh Profitabilitas, Likuiditas, Size dan Leverage Perusahaan terhadap Yield Obligasi Dengan Peringkat Obligasi Sebagai Variabel Intervening. Universitas Jenderal Soedirman.

Froot, K., Scharfstein, D., Stein, J., 1993. Risk Management: Coordinating Investment and Financing Policies. Journal of Finance. 48, 1629-1658.

Gay, G. D, Lin, C., Smith, S. D., 2011. Corporate Derivatives Use and the Cost of Equity. Journal of Bank and Finance. 35, 1491-1506.

Ghazali, Imam. 2005. Aplikasi Analisis Multivariate dengan Program SPSS. Semarang: Universitas Diponegoro.

Hanafi, Mamduh M. 2006. Manajemen Risiko. Yogyakarta: UNIT PENERBIT DAN PERCETAKAN SEKOLAH TINGGI ILMU MANAJEMEN YKPN.

Hartono, Jogiyanto. 2014. Teori Portofolio dan Analisis Investasi, Edisi Kesembilan. Yogyakarta: BPFE-Yogyakarta.

Howton, S., Perfect, S., 1998. Currency and Interest-rate Derivatives Use in US Firms. Finance Management. 27, 111-121.

Hull, John C. 1993. Options, Futures, and Other Derivative Securities. Englewood Cliffs, New Jersey: Prentice-Hall International, Inc.

Johansyah, Difi A. Oktober, 2013. Gerai Info Bank Indonesia, Edisi 43. hlm.2

Jordan, B. D., Miller, T. W., Dolvin, S. D. 2012. Fundamentals of Investments: Valuation and Management. New York: McGraw Hill.

Klock, M.S., Mansi, S.A., Maxwell, W.F., 2005. Does Corporate Governance Matter to Bondholders?. Journal of Finance Quantitative and Analysis. 40, 693-719.

Madura, Jeff. 2003. Financial Markets and Institutions, Sixth Edition. United States of America: Thomson South-Western.

Mayers, D., Smith, C., 1982. On the Corporate Demand for Insurance. Journal of Business. 55, 281-296.

McDonald, Robert L. 2009. Fundamentals of Derivatives Markets. New York: Pearson Education, Inc.

Ross, Stephen A. dkk. 2008. Corporate Finance Fundamentals. Singapore: The McGraw-Hill Companies, Inc.

Santoso, Singgih. 2000. BukU Latihan SPSS Statistik Parametrik. Jakarta: PT. Elex Media Komputindo.

Sudana, I Made. 2011. Manajemen Kevangan Perusahaan, Teori dan Praktik. Jakarta: Penerbit Erlangga.

Sudiyatno, B., Irsad, M. 2011. Menguji Model Tiga Faktor Fama dan French dalam Mempengaruhi Return Saham: Studi pada Saham LQ45 di Bursa Efek Indonesia. Jurnal Bisnis dan Ekonomi. 18, 126-136.

Sundjaja, R. S., Barlian, I. 2003. Manajemen Keuangan 2. Jakarta: Literata Lintas Media. 
Vicki Lineous Suryagari

Fitri Ismiyanti

Utomo, Lisa Linawati. 2000. Instrumen Derivatif: Pengenalan dalam Strategi Manajemen Risiko Perusahaan. Jurnal Akuntansi dan Keuangan. Vol. 2 No. 1, 53-68.

Weston J. F., Brigham, E. F.1985. Dasar-dasar Manajemen Kevangan Jilid 1, Diterjemahkan oleh Khalid, A. Q. Bandung: PT. Gelora Aksara Pratama.

Wirartha, Made I. 2006. Metodologi Penelitian Sosial Ekonomi. Yogyakarta: CV. Andi Offset.

Ziebart, David A dan Reiter, Sara A. 1992. Bond Ratings, Bond Yields and Financial Information. Contemporary Accounting Research, 9 (1), pp:252- 282. 